\title{
PERAN STRATEGIS DAN KOMPETENSI PUBLIC RELATIONS RUMAH SAKIT INDONESIA DI ERA DISRUPTIF
}

\author{
Mahdalena Lubis \\ Universitas Mercu Buana Jakarta, Indonesia \\ mahdalena.lubis@mercubuana.ac.id
}

\begin{abstract}
Currently the hospital is being faced by the National Health Insurance disruptor which demands all hospitals to be aware of the emergence of competition and digitalization innovation in providing services and gaining public interest. Hospitals are required to adapt quickly to changes that occur in real time, but some of the roles and competencies of hospital public relations are not yet capable in carrying out their duties. This study aims to describe the role and competence of hospital public relations participants who took the competency test as many as 87 people during 2017-2019 from various regions in Indonesia. This qualitative case study descriptive study uses a mix of methods, surveys collect hospital's public relations personal data and in-depth interviews with representative subjects to get a complete picture. Data were analyzed using interactive techniques and triangulation techniques to validate data so that the data obtained would be more accurate. Strategic role refers to positions in structural and competence refers to the results of competency tests. The results of this study stated that most hospital public relations have a weak role and competence in dealing with the disruptive era. Education, experience and continuous training have a close relationship to become competent public relations. Efforts and solutions made in overcoming the existing reality are outlined in conclusions and suggestions.
\end{abstract}

Keywords: Role, Competence, Public Relations, Disruptive

\begin{abstract}
ABSTRAK
Saat ini rumah sakit sedang di hadapkan oleh disruptor Jaminan Kesehatan Nasional yang menuntut seluruh rumah sakit untuk sadar munculnya pesaingan dan inovasi digitalisasi dalam memberikan layanan dan meraih animo masyarakat. Rumah sakit dituntut beradaptasi dengan cepat terhadap perubahan yang terjadi secara realtime, namun sebagian peran dan kompetensi humas rumah sakit belum mumpuni dalam melakukan tugasnya. Penelitian ini bertujuan menggambarkan peran dan kompetensi humas rumah sakit yang mengikuti uji kompetensi BNSP sebanyak 87 orang selama tahun 2017-2019 dari berbagai daerah di Indonesia. Penelitian deskriptif kualitatif studi kasus ini menggunakan mix metode, survey mengumpulkan data personal humas rumah sakit dan wawancara secara mendalam kepada subjek representatif untuk mendapatkan gambaran seutuhnya. Data dianalisis menggunakan teknik interaktif dan teknik triangulasi untuk pengesahan keabsahan data sehingga data yang diperoleh lebih akurat. Peran strategis mengacu pada jabatan dalam struktural dan kompetensi mengacu pada hasil uji kompetensi. Hasil penelitian ini menyatakan sebagian besar humas rumah sakit memiliki peran dan kompetensi yang lemah dalam menghadapi era disruptif. Pendidikan, pengalaman dan latihan yang berkesinambungan mempunyai berhubungan erat untuk menjadi humas yang kompeten. Upaya dan solusi yang dilakukan dalam mengatasi realitas yang ada diuraikan dalam kesimpulan dan saran.
\end{abstract}

Kata Kunci : Peran, Kompetensi, Humas, Disruptif

\section{PENDAHULUAN}

Perkembangan teknologi informasi mengakibatkan perubahan sedemikian cepat sehingga menuntut hubungan masyarakat (humas) rumah sakit Indonesia harus mampu memahami, menangani, mempengaruhi dan

membuat keputusan yang cepat dan tepat atas perubahan yang terjadi secara realtime.

Di era disrupsi perusahaan juga berhadapan dengan publik digital yang semakin tahun terus bertambah secara eksponen atau yang disebut 
sebagai publik tak kasat mata. Semua ini terjadi karena kita sedang memasuki sebuah era baru yang disebut dengan era disruptif. Sebuah era dimana segala sesuatu terjadi secara random, baik hal positif maupun negatif dapat menjadi viral hanya dalam hitungan detik. (Kasali, 2017, 22-32).

Contoh kasus rumah sakit yang sangat viral dan terjadi dalam hitungan jam dan banyak menyita perhatian publik adalah kasus Bayi Deborah yang meninggal di Rumah Sakit Mitra Keluarga Kalideres dengan issue uang pangkal. Kasus viral ini sampai mengalahkan trending kasus vaksin palsu (Umarjianto - Kongres Perhumasri - 2018).

Sebelum media digital berkembang, rumah sakit sehari hari merupakan gudang krisis setiap hari menerima dan melayani pasien semakin hari semakin rentan diguncang krisis, apalagi dengan adanya regulasi dan sistem baru dari disruptor Jaminan Kesehatan Nasioanal (JKN) dan Badan Penyenggara Jaminan Sosial Kesehatan (BPJS), sistem ini mengharuskan rumah sakit mau tidak mau harus berubah dan menjadi lebih efektif dan efisien, banyak rumah sakit yang tidak siap dengan perubahan ini.

Regulasi menuntut rumah sakit harus mengikuti akreditasi guna memberikan layanan kesehatan yang bermutu sesuai standart nasional kepada semua masyarakat melalui sistem digital terintegrasi, mudah diakses dan dengan biaya yang murah. Terjadilah ketidaksesuaian antara kemampuan yang diberikan rumah sakit dengan ekspektasi publik, maka kriris tidak dapat dielakkan dan bisa terjadi kapan saja. (PR-Indonesia, 2018).

Selain JKN, hadirnya Masyarakat Ekonomi Asean (MEA) juga membuat suasana indusrti rumah sakit menjadi lebih kompetitif, rumah sakit dari luar negeri yang sangat mengerti pentingnya public relations (PR) sangat mudah menggerakkan organisasi melalui branding dengan memanfaatkan media digital. (www.yankes.kemkes.go.id).

Selain masalah eksternal, masalah internal rumah sakit dapat dikatakan cukup rumit dan unik. Rumah sakit sebagai usaha padat modal, padat ilmu pengetahuan dan teknologi, padat sumber daya manusia, padat aturan, ada 26 profesi yang beragam dalam satu rumah sakit dan mempunyai kepentingan dan masalah yang sekaligus menjadi padat masalah. Di sinilah letak peran penting PR rumah sakit (Kholisoh : $2015: 196)$

Permasalahannya, peran dan kompetensi PR rumah sakit masih belum optimal karena sebagian besar manajemen rumah sakit bahkan PR nya sendiri belum memahami peran dan fungsinya dengan benar, akibatnya kompetensi mereka kurang terasah karena jarang dilibatkan dalam keputusan manajemen (Umarjianto Kongres Perhumasri : 2018)

Permasalahan yang sama juga diungkapkan dalam penelitian terdahulu oleh Chintya, Angga dan Hutomo (2015 : 7-100) dengan judul Tingkat Kompetensi dan Kinerja Praktisi Public Relations Rumah Sakit di Jawa Tengah. Sebagian besar PR rumah sakit memiliki kompetensi rendah yang mengacu pada aktivitas dan frekuensi kerja PR. Penelitian deskriptif kuantitatif ini menggunakan kategori tingkat pendidikan, latar belakang pendidikan, jabatan dan tingkat kompetensi di tujuh rumah sakit. $90 \%$ populasi peserta yang di teliti jabatan strukturalnya adalah hanya tingkat staff.

Hal yang sama juga diungkapan oleh penelitian terdahulu oleh Zulfikar, Sultan dan Kahar (2017 : 98). "Peran Humas Dalam Meningkatan Citra Rumah Sakit Dr. Wahidin Sudirohusodo Sebagai Rumah Sakit Berstandar Internasional". Penelitian kualitatif pendekatan deskriptif ini mengungkapkan bahwa peran humas rumah sakit kurang strategis, staff \& kabag humas ditempatkan dalam unit pengaduan dan merangkap menjadi pemasaran. Mereka menangani hal hal bersifat teknis dan fasilitaror terbatas seperti mengatasi keluhan pelanggan dan juga sebagai pemasaran, sehingga peran PR menjadi tidak terlihat.

Penelitian Safiti, Bakti dan Hafiar (2019 : 50-51) "Profesi Humas Rumah Sakit : Antara Profesionalisme \& Humanisme" penelitian deskriptif kualitatif ini pun menyatakan hal yang sama bahwa peran humas rumah sakit hampir tidak terlihat ada. 
Sedangkan penelitian peneliti melihat dari sisi humas rumah sakit yang telah mengikuti uji kompetensi berdasarkan BNSP tahun 20172019 sebanyak 87 humas rumah sakit dari seluruh Indonesia mulai dari staff sampai level top manajemen. Peneliti menggunakan data survey yang sudah di kategorikan dan dianalisis dan mengkombinasikannya dengan wawancara dengan subjek yang representative. Dengan demikian mendapatkan gambaran permasalahan dan solusi yang lebih menyeluruh.

Berdasarkan kompleksitas permasalahan di atas, peran PR seharusnya memperlancar proses pengambilan keputusan di berbagai level organisasi, melakukan evaluasi terhadap sikap publik, mengidentifikasi kebijakan dan prosedur seseorang atau sebuah perusahaan terhadap publiknya, menyusun rencana serta menjalankan program-program komunikasi untuk memperoleh pemahaman dan penerimaan Keller (2008), Wilcox dan Warent, (2006) dalam Kholisoh (2015).

Permasalahan yang dihadapi rumah sakit dalam mengahdapi era digital/disrupsi semakin kompleks karena akses informasi dan reputasi semakin lebih terbuka dan mudah diakses masyarakat. (Safitri, Bakti dan Hafiar, 2019 : 49)

Unutk itu PR diharapkan memiliki peran strategis dan untuk mempermudah rumah sakit dalam menggerakkan bisnis. (Gurning dalam Amie, 2015 : 9). PR harus mampu menggunakan cara baru dalam merubah strategi komunikasi dalam upaya meraih animo masyarakat, terutama diera disruptif dan digitalisasi.

Dalam penelitian ini, peran stategis $P R$ mengacu pada konsep Cutlip dan Center (2011 : 46-47) dalam adalah sebagai Penasehat Ahli, Fasilisator Komunikasi, Fasilisator Proses Pemecahan Masalah dan Teknisi Komunikasi.

Saat mengahadapi era disruptif peran PR expert prescriber atau penasehat ahli dianggap oleh manajemen sebagai otoritas dalam menhadapai persoalan dan solusinya. Mampu mendefenisikan problem, mengembangkan program dan bertanggungjawab penuh penuh atas implementasinya. Cutlip (2011 : 46). Dalam mengahdapi era ketidakpastian, digitalisasi dan sangat kompetitif.

Pernyataan Cutlip di dukung oleh Grunnig (1992) dalam Amie (2015 : 9), PR biasanya tidak mempunyai kebebasan untuk bertindak sebagai seorang profesional, kecuali jika dia duduk dalam jajaran top manajemen atau strategis yang disebutnya sebagai koalisi dominan penentu dalam pengambilan keputusan dan yang mengendalikan berputarnya roda organisasi.

Selain peran strategis, PR juga harus mempunyai kompetensi yang tinggi agar mudah menjalankan kinerja, konsep kompetensi mengacu padaUU No. 13/ 2003 pasal 1 ayat 10 tentang ketenagakerjaan yang dilaksanakan oleh Badan Nasional Sertifikasi Profesi. Kompetensi didefinisikan sebagai kemampuan kerja setiap individu yang mencakup aspek pengetahuan, keterampilan, dan sikap yang sesuai dengan standar yang ditetapkan.

Seperti yang dinyatakan Laksamana (2018) Di era Disruptif PR harus mempunyai kompetensi multitasking yaitu mengerti aspek bisnis organisasi dari hulu hingga hilir. Contohnya : PR harus mampu menulis untuk membangun opini publik, mengintegrasikan berbagai teknologi baru, menciptakan model mengukur kinerja, mendesain komunikai organisasi terpadu, merencanakan program media relations yang inklusif, teknik lobby dan negosiasi, kemampuan berorganisasi, kreatif, mampu merangkul stakeholder, berpikir atau berwawasan global, mematuhi etika profesi dan terlibat aktif dalam diskusi public. Laksamana (2018), Nova ( 2011 : 48) dan Hartini (2019 : 41-43)

Penelitian ini bertujuan menggambarkan peran dan kompetensi humas rumah sakit yang mengikuti uji kompetensi sebanyak 87 orang selama tahun 2017-2019 dari berbagai daerah di Indonesia dengan malakukan survey data

\section{METODOLOGI}

Paradigma penelitian menggunakan konstruktivis, merupakan antitesis dari dari 
paham yang meletakkan pengamatan dan objektivitas dalam menemukan suatu realitas atau ilmu pengetahuan. (Hidayat, $2003: 3$ )

Metode penelitian ini menggunakan mix methods, yaitu suatu langka penelitian dengan menggabungkan dua bentuk pendekatan dalam penelitian, yaitu kualitatif dan kuantitatif. (Creswell, $2010: 5$ ).

Strategi ini dapat dilakukan dengan survey data dengan kategori yang sudah ditetapkan untuk dianalisa dan digambarkan, penelitian ini menggunakan teknik campuran bertahap, menggabungkan data yang ditemukan dari suatu metode dengan metode lainnya lalu diikuti dengan interview untuk mendapatkan gambaran yang mendalam.

Pendekatan mix methods diperlukan untuk menjawab rumusan masalah, pendekatan kuantatif dilakukan peneliti dengan memberikan survey pertanyaan berdasarkan kategori nama rumah sakit, privat atau publik, usia, masa kerja, jenis kelamin, pendidikan, jabatan dan hasil uji kompetensi.

Peneliti melakukan survey koesioner dikuti oleh 87 humas dari 51 rumah sakit dari seluruh Indonesia yang mengirimkan humasnya untuk uji kompetensi berdasarkan BNSP tahun 2017 $-2019$.

Studi kasus merupakan penyelidikan mendalam (in-depth study) mengenai suatu unit sosial sedemikian rupa sehingga menghasilkan gambaran yang terorganisasikan dengan baik dan lengkap mengenai unit sosial tersebut. (Kholisoh, 2015).

Subyek penelitian adalah informan penelitian yang harus benar-benar representatif yang memahami dengan baik peran dan tantangan humas rumah sakit di Indonesia yaitu Kepala Bagian Opini Publik di Kementrian Kesehatan, Ketua Kompartemen Public Relations dan Marketing di Persatuan Rumah Sakit Indonesia (Persi) dan Ketua Umum di organisasi Perhimpunan Humas Rumah Sakit Indonesia (Perhumasri). Penelitian bersifat value-bound (Yin, 2006), sehingga peneliti terlibat secara aktif bersama subyek untuk memperoleh kebenaran.
Jenis penelitian kualitatif ini untuk mendeskripsikan, mencatat, menganalisis, menginterpretasikan kondisi yang terjadi, dan berusaha untuk memperoleh informasi mengenai keadaan yang ada dalam meneliti sekelompok manusia atau suatu objek dengan tujuan membuat deskriptif, gambaran atau lukisan secara sistematis, faktual dan akurat mengenai fakta-fakta dan fenomena yang diselidiki. (Sugiono, 2008 dalam Lena, 2017).

Untuk teknik pengumpulan data, peneliti memperoleh data yang diperlukan dalam penelitian ini, teknik yang digunakan peneliti adalah mengumpulkan data survey koesioner, wawancara dengan informan, dan observasi serta pengumpulan data pendukung untuk digambarkan sebagai data primer. Responden penelitian untuk kuesioner adalah humas rumah sakit yang sudah tersertifkasi.

Sedangkan data sekunder diperoleh dari data yang sudah jadi ( tersedia ) melalui publikasi dan informasi yang dikeluarkan di berbagai organisasi atau perusahaan, termasuk majalah PR Indoensia, jurnal, foto kegiatan, surat kerjasama, website, media sosial, bukubuku, studi pustaka, majalah dan sebagainya. (Ruslan, 2010:30)

Analisis data diperoleh dari proses mencari dan menyusun secara sistematis data yang diperoleh dari hasil analisa data survey, wawancara, catatan lapangan dan dokumentasi melalui mengorganisasikan data kedalam kategori, menjabarkan ke dalam unit-unit, melakukan sintesa menyusun ke dalam pola, mengklasifikasikan hal-hal penting yang akan dipelajari dan membuat kesimpulan, sehingga mudah dipahami oleh peneliti dan oleh pembaca. (Moleong, 2006 : 167).

Menurut Miles dan Huberman dalam Denzin \& Lincoln (2009 : 592) teknik analisis data model interaktif yaitu kolektif data, reduksi data, penyajian data, serta penarikan kesimpulan atau verifikasi, yang secara interaktif saling berhubungan selama

Sedangkan untuk menguji keabsahan data yang didapat sehingga benar-benar sesuai dengan tujuan dan maksud penelitian, maka menggunakan teknik triangulasi, yaitu dengan 
sumber dan metode, yang berarti membandingkan dan mengecek derajat balik kepercayaan suatu informasi yang diperoleh melalui waktu dan alat yang berbeda secara kualitatif (Moleong, 2006 : 330 ).

Tujuan penggunaan teknik ini bukan untuk mencari kebenaran tentang beberapa fenomena, melainkan lebih kepada peningkatan pemahaman peneliti terhadap apa yang ditemukan.

Dari pengertian metode penelitian sampai teknik pemeriksaan keabsahan data maka pendekatan kualitatif bertujuan mengemukakan atau menjabarkan fenomena yang ada pada lingkungan sosial tertentu. Hal ini sejalan dengan peneliti, karena peneliti bermaksud menganalisa kata-kata tertulis atau lisan dari wawancara mendalam dengan narasumber serta dokumen yang mendukung dan kemudian dianalisa secara mendalam dengan tujuan untuk meneliti konsep peran dan kompetensi PR.

\section{HASIL DAN PEMBAHASAN}

\section{Peran dan Kompetensi Humas Rumah Sakit}

Data di kelola oleh peneliti berdasarkan jumlah rumah sakit, gender, masa kerja, jabatan, pendidikan dan kompetensi kehumasan berdasarkan BNSP sejak tahun 2017 - 2019.

\section{Jumlah Rumah Sakit Yang Mengikuti Uji Kompetensi}

Sampai April - 2018 tercatat jumlah rumah sakit yang ada di Indonesia sebanyak 2.820 (www.persi.or.id), namun hanya 87 humas dari $51(2.2 \%)$ rumah sakit mengikuti pelatihan dan uji kompetensi kehumasan yang diadakan oleh Persi. Artinya masih ada 98,8\% rumah sakit yang tidak mengikutkan PRnya untuk pelatihan dan uji kompetensi. Hal ini disebabkan oleh kurangnya pemahaman pentingnya peran PR kepada pemilik atau petinggi rumah sakit

PR yang mengikuti uji kempetensi terdiri dari rumah sakit pemerintah $53 \%$ dan rumah sakit swasta $47 \%$. Sebagian besar humas yang mengikuti uji kompetensi dan pelatihan kehumasan berasal dari daerah $45.1 \%$ dan $54.9 \%$ dari Jakarta.
Tabel 1. Jumlah rumah sakit dan humas yang mengikuti uji kompetensi dan pelatihan kehumasan.

\begin{tabular}{llllll}
\hline Uraian & Jumlah & $\begin{array}{l}\text { RS. } \\
\text { Private }\end{array}$ & $\begin{array}{l}\text { RS. } \\
\text { Publik }\end{array}$ & $\begin{array}{l}\text { DKI } \\
\text { Jakarta }\end{array}$ & Daerah \\
\hline $\begin{array}{l}\text { Rumah } \\
\text { Sakit }\end{array}$ & 51 & 24 & 27 & 23 & 28 \\
\hline Humas & 87 & 38 & 49 & 28 & 59 \\
\hline
\end{tabular}

Sumber : koesioner dikelola oleh peneliti

Pernyataan yang sama disampaikan oleh ketua Perhimpunan Humas Rumah Sakit Indonesia (Perhumasri), bahwa penyebab minimnya jumlah rumah sakit yang mengirimkan pelatihan dan uji sertifikasi kehumasan, terletak pada manajemen dan humas rumah sakit tidak memahami fungsi humas dengan benar.

Ketua Umum Perhumasri Anjari Umarjianto:

"Masih banyak rumah sakit yang belum mengetahui pentingnya peran $\mathrm{PR}$, hal ini bisa disebabkan karena manajemen atau PRnya sendiri tidak memahami fungsinya dengan baik dan benar. Akibatnya, selama ini PR hanya menjadi tukang foto, terima keluhan, bernegosiasi kalau ada unjuk rasa, bahkan ruangannya di pojok sempit yang jarang orang lewat."

\section{Usia, Tingkat Pendidikan dan Latar Belakang Pendidikan}

Usia dibagi dalam katagori 20-30 tahun, 3140 tahun, 41-50 tahun dan >50 tahun, ditemukan usia 41-50 tahun memberikan jumlah tertinggi $45.98 \%$, artinya PR rumah sakit rata rata memiliki usia yang senior dan berpengalaman.

Tingkat pendidikan dibagi atas kategori SMA/sederajat, D1-D4, S1, dan S2. PR rumah sakit rata rata meiliki tingkat pendidikan yang baik yaitu sarjana S1 51.72\%. Karakteristik latar belakang pendidikan, peneliti membagi ke dalam sarjana ilmu komunikasi dan yang tidak memiliki latar belakang ilmu komunikasi. Berdasarkan hasil temuan diperoleh hasil bahwa praktisi humas yang 'bukan' lulusan pendidikan ilmu komunikasi atau kehumasan 
sebesar 91.95\%. Angka ini menunjukkan humas rumah sakit memiliki tingkat pendidikan yang baik namun sebagian besar bukan berlatar belakang pendidikan ilmu kehumasan.

Ketua Umum Perhumasri;

"Kondisi dilapangan ditemukan humas berlatar belakang pendidikan perawat, ahli gizi, dokter, bidan, kesehatan masyarakat dan lain sebagainya."

Hal ini dikarenakan rumah sakit merasa lebih mudah mengarahkan sumberdaya manusia yang berasal dari internal berlatar belakang kesehatan untuk menjadi PR.

Ketua Umum Perhumasi;

"Humas rumah sakit memang rata rata tidak memiliki "darah biru" ilmu komunikasi, sumber daya manusia yang ditempatkan dibagian humas rumah sakit adalah karyawan internal sendiri karena lebih mudah mengambil dan mengarahkan karyawan yang mengerti kesehatan tanpa memandang latar belakang pedidikan".

Ditemukan lima dari tujuh PR yang mempunyai pendidikan komunikasi mempunyai peran strategis yaitu manager, namun kompetensinya bervariasi dari madya, ahli dan managerial. PR sakit dengan pendidikan kehumasan atau komunikasi bukan berarti mereka langsung kompeten dalam bekerja di rumah sakit, jika dilihat berdasarkan usia, jabatan dan masa kerja, maka humas rumah sakit yang mempunyai ilmu kehumasan untuk dapat memiliki peran strategis dan kompetensi tinggi, tentu harus ditempah dengan pengalaman kerja dan menjadi pribadi yang dewasa terlebih dahulu.

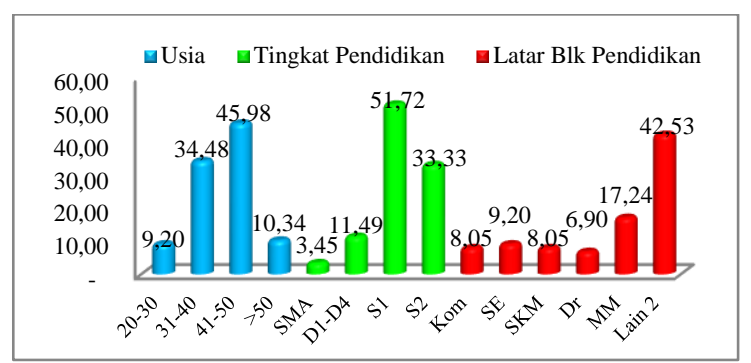

Gambar 1. Persentase berdasarkan usia, pendidikan dan latar belakang pendidikan. Sumber : koesioner dikelola oleh peneliti

Ketua Umum Perumasri;

"Praktisi PR yang berlatar belakang pendidikan ilmu kehumasan atau komunikasi bukan berarti mereka langsung kompeten dalam bekerja di rumah sakit, semua membutuhkan proses. Menjadi PR rumah sakit sangat kompleks permasalahannya, selain urusan nyawa manusia juga harus mengenal 60 profesi yang ada di rumah sakit”.

\section{Berdasarkan Pengalaman Kerja, Jabatan dan Kompetensi.}

Masa kerja dibagi atas $<5$ tahun, 6-10 tahun, 11-15 tahun, dan ternyata usia $>15$ tahun yang memiliki kontribusi terbesar $56.31 \%$. Di jabatan strukutural, peneliti membagi dalam staff officer, supervisor, manager, direktur/CEO. Berdasarkan hasil temuan, jabatan manager menempati jumlah tertinggi $50.57 \%$. Ini menunjukkan peserta yang dikirim oleh rumah sakit untuk mengikuti pelatihan humas dan uji kompetensi paling banyak adalah mempunyai peran strategis yaitu tingkat manageral yang sudah memiliki masa kerja rata rata diatas 15 tahun.

Tingkat kompetensi terbagi atas muda (rendah), madya (sedang), ahli dan managerial (tinggi). Berdasarkan hasil uji kompetensi ditemukan bahwa kompetensi madya adalah yang tertinggi $37.93 \%$. Ini menunjukkan rata rata praktisi $\mathrm{PR}$ rumah sakit mempunyai kompetensi sedang, artinya kurang mampu melakukan keseluruhan dimensi aktivitas sehingga kinerja yang dihasilkan belum maksimal karena hanya mengacu pada satu 
dimensi aktivitas yang sering dilakukan dan administratif.

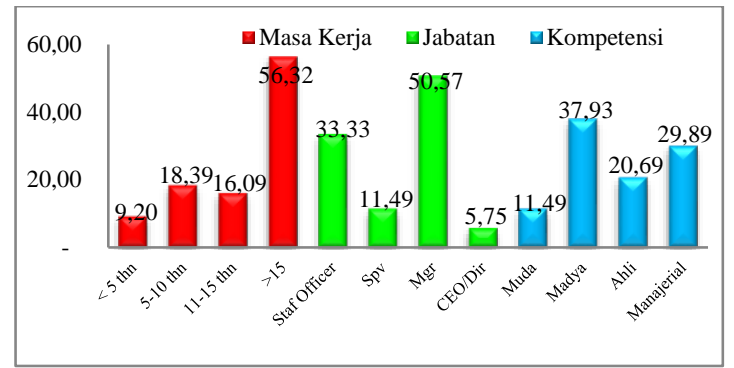

Gambar 2. Jumlah angka berdasarkan masa

kerja, jabatan dan kompetensi.

Sumber : koesioner dikelola oleh peneliti

Untuk menjawab tantangan humas rumah sakit yang mempunyai kompetensi muda dan madya, Perhumasri melakukan kegiatan sosialisasi dan pelatihan workshop secara berkesinambungan untuk meningkatkan kompetensi PR rumah sakit.

Ketua Umum Perhumasri;

"Sejak tahun 2013, workshop dan seminar humas sudah kami lakukan awareness, baik untuk PR maupun untuk para CEO rumah sakit, namun masih terbatas. Pelatihan yang pernah kami lakukan misalnya media handling, menangani keluhan pelanggan, memahami isu, mengatasi krisis dan lainnya. Dan dari sinilah semakin banyak rumah sakit yang mengenal dan memahami profesi PR. Terakhir bulan November 2019 kongres kedua untuk menguatkan organisasi dan pelatihan kehumasan menjadi agenda yang intensif kami lakukan”.

\section{Hubungan Pendidikan, Masa Kerja, Jabatan Dan Kompetensi}

Idealnya, semakin lama masa kerjanya maka semakin ahli dan berkembang humas rumah sakit dalam bidangnya. Namun pada gambar 3, masa kerja > 15 tahun di dominasi oleh kompetensi madya dan managerial, sedangkan kompetensi ahli lebih sedikit. Ini menunjukkan korelasi negatif, masa kerja belum tentu ahli dalam bidangnya.

Tabel 2. Kompetensi dan masa kerja.

\begin{tabular}{lcccc}
\hline \multirow{2}{*}{ Masa Kerja } & \multicolumn{5}{c}{ Kompetensi } \\
\cline { 2 - 5 } & Muda & Madya & Ahli & Managerial \\
\hline$<\mathbf{5}$ & 1 & 7 & 0 & 0 \\
\hline $\mathbf{5 - 1 0}$ & 3 & 3 & 4 & 6 \\
\hline $\mathbf{1 1 - 1 5}$ & 2 & 6 & 3 & 3 \\
\hline$>\mathbf{1 5}$ & 4 & 17 & 11 & 17 \\
\hline Jumlah & $\mathbf{1 0}$ & $\mathbf{3 3}$ & $\mathbf{1 8}$ & $\mathbf{2 6}$ \\
\hline
\end{tabular}

Sumber : koesioner dikelola oleh peneliti

Antara Pendidikan dan kompetensi praktisi PR, ditemukan korelasi positif yaitu semakin tinggi pendidikan praktisi PR maka kompetensinya semakin baik. Begitu juga sebaliknya, makin rendah pendidikannya maka kompetensinya juga rendah.

Tabel 3. Pendidikan dan kompetensi.

\begin{tabular}{lcccc}
\hline \multirow{2}{*}{ Pendidikan } & \multicolumn{4}{c}{ Kompetensi } \\
\cline { 2 - 5 } & Muda & Madya & Ahli & Managerial \\
\hline SMA & 0 & 3 & 0 & 0 \\
\hline D3 & 2 & 4 & 1 & 3 \\
\hline S1 & 7 & 18 & 9 & 11 \\
\hline S2 & 1 & 8 & 8 & 12 \\
\hline
\end{tabular}

Sumber : koesioner dikelola oleh peneliti

Peran strategis dan kompetensi PR merupakan persamaan dari posisi atau jabatan dan kompetensi yang di miliki oleh seorang PR. Pada tabel 2 ditemukan fakta bahwa kompetensi madya berada paling tinggi dari level staff sampai CEO. Uniknya, beberapa peran PR rumah sakit dilakukan oleh CEO dan direktur.

Dari analisis antara jabatan struktural dan tingkat kompetensi PR rumah sakit didominasi dengan jabatan manager dengan kompetensi tinggi (ahli dan managerial). Idealnya, semakin strategis peran PR maka kompetensi yang diharapakan mencapai level ahli. Artinya uji kompetensi ini mendapat perhatian dan tindaklanjut oleh para pihak berkepentingan di rumah sakit. Dibuktikan dengan banyaknya manager yang di kirim untuk mengikuti pelatihan dan uji kompetensi yang diadakan Perhumasri sejak 2017-2019.

Namun sebanyak 14 jabatan manager rumah sakit masih melakukan kegiatan rutin, administratif dan mengelola kegiatan kehumasan atau belum ahli dalam bidangnya. Hal ini menjadi perhatian bagi manajemen 
rumah sakit, karena sangat tidak efektif diera disruptif manager dengan kompetensi yang rendah atau sedang. Sebaliknya beberapa PR yang memiliki kompetensi tinggi justru berada di level staff dan supervisor. Diperlukan pelatihan secara berkesinambungan untuk melatih kompetensi PR rumah sakit dan mereposisi jabatan.

Tabel 4. Hubungan antara jabatan dan kompetensi.

\begin{tabular}{ccccc}
\hline \multirow{2}{*}{ Jabatan } & \multicolumn{4}{c}{ Kompetensi } \\
\cline { 2 - 5 } Staff & 8 & 17 & 2 & 2 \\
\hline Spv & 1 & 2 & 5 & 2 \\
\hline Mgr & 1 & 13 & 11 & 19 \\
\hline Dir/Wadir & & & 3 \\
\hline CEO & \multicolumn{1}{c}{} \\
\hline
\end{tabular}

Sumber : koesioner dikelola oleh peneliti

\section{Peran Strategis, Kompetensi dan Era Disruptif}

Data rumah sakit pemerintah (publik) ditemukan tingkat kompetensi rendah-sedang (muda \& madya) lebih banyak dibanding rumah sakit swasta (privat), namun kompetensi manajerial kedudukannya sama. Ini menunjukkan bahwa rumah sakit swasta lebih kompetitif dibanding rumah sakit pemerintah.

Tabel 5. Kompetensi rumah sakit publik dan privat

\begin{tabular}{lllll}
\hline RS & Muda & Madya & Ahli & Managerial \\
\hline Publik & 7 & 22 & 7 & 13 \\
\hline Privat & 3 & 11 & 11 & 13 \\
\hline
\end{tabular}

Sumber : koesioner dikelola oleh peneliti

Rumah sakit menjadi salah satu industri yang relatif tidak cukup siap mengadapi gelombang baru bernama era disruptif dimana teknologi informasi, media sosial dan keterbukaan informasi berkembang cepat membuat publik semakin sadar terhadap haknya.

Program JKN yang dilaksanakan oleh BPJS Kesehatan membuat regulasi baru yaitu layanan kesehatan rumah sakit tersistem melalui digitalisasi (pendaftaran kepesertaan, laporan obat, laporan diagnosa penyakit, nama pasien, pembayaran dan seterusnya), mudah diakses masyarakat, dan standarisasi harga yang terjangkau. Selain itu rumah sakit yang mendaftar ke BPJS terlebih dahulu wajib ikut akreditasi (standarisasi nasional rumah sakit dan sertifikasi profesi).

Ketua Umum Perhumasri;

"Masih banyak rumah sakit yang belum siap menghadapi era disruptif, perkembangan teknologi informasi yang berkembang begitu cepat dan persaingan rumah sakit dari luar negeri yang sudah berani merambah ke Indonesia - sementara rumah sakit dalam negeri tidak boleh berpromosi membuat pemerintah harus berubah dengan mengeluarkan regulasi dan sistem baru yaitu JKN yang dilaksanakan oleh BPJS Kesehatan. Sistem ini mengharuskan rumah sakit mau tidak mau harus berubah dan menjadi lebih efisien dan mempunyai standart mutu yang sama melalui akreditasi. Rumah sakit yang merupakan gudang krisis - setiap hari menerima dan melayani pasien - ketika baru beradaptasi dengan regulasi belum sejalan dengan animo masyarakat yang begitu tinggi akibatnya makin hari semakin rentan diguncang krisis".

Krisis di rumah sakit sekarang ini semakin sering terjadi di era disrupsi ini, pasien yang tidak puas dengan layanan rumah sakit dengan sigap memviralkan melalui media sosial, sehingga media masa dengan cepat mengetahuinya.

Ketua Umum Perhumasri;

"Karena baru beradaptasi dengan era disrupsi, keluhan pasien tidak dapat di hindarkan baik di media massa, media sosial dan yang datang langsung kerumah sakit. Karena terjadi ketidaksesuaian antara kemampuan yang diberikan rumah sakit dengan ekspektasi publik, maka kriris tidak dapat dielakkan dan bisa terjadi kapan saja". 
Berdasarkan data rumah sakit, masih ada sebagian besar rumah sakit yang belum mengerti tentang PR dan tidak menjadikan urgensi di era disruptif ini.

Ketua Umum Perhumasri;

"Terbukti masih sedikit rumah sakit yang mengirimkan humasnya untuk ikut pelatihan kehumasan. Tapi karena sedari awal profesi PR dan urgensi mengelola reputasi rumah sakit tidak termasuk dalam strategi manajemen rumah sakit, humas yang merupakan ilmu yang sudah tua menjadi seperti baru di industry rumah sakit. Maka ketika terjadi krisis di rumah sakit, ratarata mereka tidak cukup berhasil menanganinya".

Kompetensi PR rumah sakit pun di tuntut semakin tinggi. Untuk itu PR harus mampu beradaptasi dengan cepat dan memiliki kompetensi yang baik.

Ketua Umum Perhumasri;

"Humas diarapkan memiliki kemampuan multi tasking, tidak hanya pengetahuan rumah sakit, namun juga berwawasan global. Mengerti digital, bisa menelurkan gagasan melalui menulis, mempunyai jejaring yang luas, mampu berkolaborasi dan harus mempunyai naungan organisasi atau berhimpun agar ketika terjadi krisis, humas mampu berkolaborasi menyelesaikan masalah. Maka humas pun harus cepat beradaptasi."

Diharapkan pemimpin dan manajemen rumah sakit harus menjadi contoh PR yang baik, paham pentingnya fungsi dan membangun sistem PR.

Ketua Umum Perhumasri;

"Harapan saya, pemimpin dan manajemen rumah sakit paham pentingnya tugas dan fungsidan sistem PR rumah sakit itu sudah terbangun. Pimpinan rumah sakit harus bisa menjadi contoh PR yang baik dan meyakinkan semua anggota rumah sakit bahwa mereka semua adalah PR. Untuk itulah organisasi Perhimpunan Humas Rumah Sakit Indonesia (Perhumasri) hadir dan bekerjasama dengan Perhimpunan Rumah Sakit Indonesia (Persi) untuk terus memberikan edukasi kepada pemangku kepentingan rumah sakit akan pentingnya PR.”

\section{Pembahasan}

Sesuai dengan tujuan penelitian, hasil olah data juga memaparkan peran strategis dan tantangan (kompetensi) humas rumah sakit Indonesia di era disruptif. Peran strategis dilihat dari jabatan dan tantangan dilihat dari hasil uji kompetensi kehumasan.

Berdasarkan data, hanya $2.2 \%$ rumah sakit yang mengirimkan PR nya untuk mengikuti pelatihan dan uji kompetensi kehumasan. Sebagian besar rumah sakit yang belum memahami pentingnya peran humas, hal ini bisa disebabkan karena manajemen dan PRnya tidak memahami fungsi PR dengan benar. Mengacu pada referesi Nova (2011) tantangan dan masa depan PR paling besar adalah di dalam internal sendiri, humas harus mampu merubah image negatif dan salah persepsi terhadap humas karena masih dianggap menghambat komunikasi, tambahan biaya pengeluaran, asosiasi yang salah, dibutuhkan jika ada krisis. Artinya masih dianggap belum perlu.

Dari data yang dianalisa ditemukan paktisi wanita lebih banyak dibanding laki-laki. Maka mengacu pada referensi yang digunakan yaitu menurut Cutlip, Center dan Bromm (2007 : 36) menyatakan bawa jumlah praktisi PR yang tergabung dalam PRSA, sebanyak $54 \%$ berjenis kelamin perempuan, maka temuan dari penelitian ini menunjukkan bawa praktisi PR rumah sakit lebih banyak di dan diminati oleh gender perempuan. Didukung oleh pendapat dari Gruning, Toth dan Hon (2001) dalam Damayanti dan Saputro (2017 : 29) bahwa banyak perempuan yang tertarik untuk bekerja sebagai public relations dan mereka dapat menggapai status profesionalisme. 
Jika dilihat dari latar belakang pendidikan dan tingkat pendidikan, praktisi PR rumah sakit sebagian besar adalah sarjana yang 'bukan' berasal dari sarjana ilmu komunikasi ataupun kehumasan. Namun terdapat enam orang dengan mendidikan komunikasi menduduki posisi manajerial (supervisor, asisten manager dan manager) dengan kompetensi tinggi ahli dan managerial. Dalam Cutlip, Center dan Bromm (2007 : 37-38) juga dikemukakan bahwa praktisi yang memiliki latar belakang pendidikan setidaknya jurnalistik akan mudah untuk mengisi posisi PR dalam sebuah organisasi. Hal ini dikarenakan menjadi sebuah syarat penting bagi seorang PR organisasi untuk mampu menjalankan fungsi PR dalam menyebarkan informasi dan menjalin relasi dengan media. Maka latar belakang pendidikan memiliki pengaruh yang sangat besar dalam kompetensi yang dimiliki seseorang.

Jika dianalisis dari kompetensi dan jabatan strategis, berdasarkan temuan dari keseluruan penelitian ini maka dapat disimpulkan bahwa $50 \%$ kompetensi muda dan madya paling banyak diposisi staff sampai manager yang melakukan fungsi komunikasi technican yaitu seseorang PR dalam melaksanakan tugas hanya berorientasi pada hal yang bersifat teknis. Perkembangan teknologi dan kompetitif bisnis di era disruptif, peran staff dengan kompetensi technican akan sulit mengambil keputusan, mengatasi masalah dan wewenangnya juga terbatas.

Menurut Cutlip, Center dan Broom (2011 : 45-47), jika seorang praktisi hanya berada pada posisi staff biasa maka praktisi tersebut hanya akan menjalankan peran teknis, hanya melakukan aktivitas seperti menulis release, membuat brosur, membuat undangan, membuat majalah internal dan eksternal dan menangani kontak dengan media. Dengan artian bahwa praktisi PR tidak terlibat dalam hal pengambilan keputusan yang terjadi dalam organisasi.

Selain itu PR dengan kompetensi rendah walaupun sudah berpengalaman $>15$ tahun kurang efektif menuduki posisi strategis (top level), begitu juga sebaliknya. Diperlukan pelatihan dan keterlibatan berkesimambungan untuk mengasah kompetensi.

Berdasarkan jabatan strategis, kompetensi dan pengalaman, sebanyak $37 \%$ PR professional menempati posisi manajer dan direktur dengan kompetesni yang tinggi dan berpengalaman, posisi ini berada dalam kelompok dominan yaitu di level top menajemen. Sejalan dengan pendapat Gruning (1992) Praktisi PR dituntut lebih profesional untuk itu perannya harus berada dalam jajaran top manajemen yaitu pihak-pihak dalam organisasi yang memiliki kewenangan lebih dalam memberi arah perkembangan organisasi termasuk menentukan visi, misi, perangkat serta struktur kelengkapan organisasi agar mempunyai kebebasan untuk bertindak. Jika unit PR menjadi bagian koalisi yang dominan yang menentukan arah organisasi, maka tujuan PR menjadi tujuan organisasi.

Jabatan strategis, kompetensi tinggi dan berpengalaman dalam bidangnya mampu melaksanakan tugas yang berorientasi pada sikap professional yaitu mendefenisikan problem, mengembangkan program, dan bertanggung jawab penuh atas implementasinya. Berkolaborasi memecahkan masalah, bagian dari tim perencanaan strategis dan menganalisis situasi problem dan lainnya. Menurut Cutlip (2009) Seorang praktisi PR yang berpengalaman dan memiliki kemampuan tinggi dapat membantu mencarikan solusi dalam menyelesaikan masalah hubungan dengan publiknya. Praktisi PR juga bertindak sebagai seorang komunikator, fasilitator dan ahli dalam bidangnya untuk membantu pihak manajemen dalam hal mendengar apa yang di inginkan dan diharapkan oleh publiknya.

Kompetensi yang diharapkan di era disrupsi berdasarkan hasil uji kompetensi yang diadakan Persi adalah Ahli dan Manajerial, yaitu; a). Mendesain dan mengintegrasikan strategi komunikasi dan pemasaran terpadu melalui berbagai teknologi baru atau memaksimalkan berbagai channel komunikasi untuk membangun opini publik dan komunikasi dua arah. b). berkoordinasi lintas fungsi dalam organisasi. c). Mengelola stakeholder. d). 
Mengelola team unit PR. e). Membuat program dan aktivitas kehumasan berbasis riset dan visi misi organisasi. f). Mengelola issue dan krisis. g. Mengevaluasi kinerja dan mengembangkan rencana kerja.

Sejalan dengan kompetensi yang diharapkan di masa depan menurut Nova (2011) dan Laksamana (2018) adalah mampu beradaptasi di era disrupsi, mengimplementasikan visi dan misi organisasi. Mendesain dan mengintegrasikan strategi komunikasi dan pemasaran terpadu melalui berbagai teknologi baru atau memaksimalkan berbagai channel komunikasi. Berwawasan global, merencanakan strategi komunikasi berbasis research skill, membuat program PR dan media relations yang inklusif. Mengidentifikasi dan merangkul berbagai stakeholder, mematuhi atau memahami etika budaya organisasi dan ke PR an. Menciptakan model untuk mengukur kinerja divisi PR, mengelola komunitas, melatih staff dan mengedukasi klien secara terus menerus. PR harus Terlibat aktif dalam diskusi publik bukan hanya mengirim pesan, dan mampu menggunakan perangkat manajemen krisis digital.

'Temuan menarik' melalui observasi dalam penelitian ini adalah, di struktur organisasi rumah sakit - PR dan marketing menjadi satu bagian karena dianggap efisien oleh manajemen rumah sakit, namun dengan kompleksitas masalah rumah sakit di era disrupsi ini, peran PR rumah sakit jadi kurang bergema karena PR lebih banyak di tuntut untuk menjadi marketing memasarkan layanan rumah sakit karena persaingan semakin kompetitif.

Observasi lainnya, kondisi dilapangan kerap ditemui rumah sakit pemerintah sebagian besar memiliki struktur PR tapi tidak mempunyai marketing. Meskipun memiliki PR, perannya sebagain besar tidak strategis dan belum mampu mewarnai manajemen. Sebaliknya di rumah sakit swasta umumnya memiliki struktur marketing, tapi sebagian besar tidak punya PR. Di rumah sakit swasta kebanyakan marketing merangkap humas dengan tujuan efisiensi biaya, bukan sebagai fungsi. Temuan ini semakin menguatkan image negatif PR sebagai beban biaya, menurut Nova (2011) Perepsi yang salah terhadap PR adalah masih dianggap sebagai tambahan biaya atau beban.

Hal inilah yang menyebabkan krisis terjadi rata rata rumah sakit tidak cukup berhasil menanganinya karena humasnya lebih banyak berperan di marketing. Padahal rumah sakit sedang memasuki era disruptif, seharusnya manajemen rumah sakit sudah aware dengan kePRan dan strategi komunikasi. Namun ditemukan juga PR rumah sakit yang sudah berdiri sendiri, contoh rumah sakit Pertamina Group dan rumah sakit Hermina Group yang sudah go public.

\section{SIMPULAN}

Pertama, peran starategis dan kompetensi PR rumah sakit di era disruptif masih banyak yang rendah-sedang, PR tidak berjalan sendiri, tentunya sangat memerlukan dukungan pemangku kepentingan rumah sakit untuk mengkonstuksi PR professional. Untuk itu, edukasi, pelatihan dan pendampingan tentang kehumasan secara berkelanjutan tidak hanya diikuti oleh PR namun juga level top manajemen agar memahami fungsi PR dengan baik. Kedua, rumah sakit harus membuat anggaran pelatihan kehumasan untuk meningkatkan peran strategis dan kompetensi PR, karena PR merupakan investasi bagi organisasi bukan beban biaya. Ketiga, peran strategis mempunyai hubungan erat dengan tingkat pendidikan, kompetensi tinggi dan pengalaman, sedangkan latar belakang pendidikan komunikasi sangat mendukung dalam melakukan tugas kehumasan dan merancang strategi komunikasi rumah sakit. Keempat, di era disrupsi, tantangan humas semakin besar, fungsi humas dituntut lebih professional dalam bidang kerjanya, untuk itu PR harus dilibatkan dalam pengambilan keputusan manajemen agar kompetensi humas semakin terasah dan meningkat. PR juga harus proaktif dan menciptakan karya nyata sehingga 
membentuk citra positif secara personal dan team di persepsi manajemen

Kelima, rumah sakit harus sakit harus terbuka dengan perubahan, bahwa menambah tenaga kerja yang memiliki latar belakang ilmu komunikasi perlu dipertimbangkan.

\section{DAFTAR PUSTAKA}

Creswell, J.W. (2013). Research Design: Pendekatan Kualitatif, Kuantitatif dan Mixed. Terjemahan Fawaid, A. Yogyakarta: Pustaka Pelajar.

Cutlip, Scot M., Allen Center, dan Glen M. Broom. (2007). Effective Public Relations. Alih bahasa oleh Tri Wibowo, B. S. edisi kesembilan. cetakan kedua. Jakarta: Kencana Prenada Media Group.

Cutlip, Scot M., Allen Center, and Glen M. Broom. (2009). Effective Public Relations. tenth edition. Pearson International Edition. NJ: Prentice Hall

Cutlip, Scot M., Allen Center, dan Glen M. Broom. (2011). Effective Public Relations. edisi kesembilan. cetakan ke empat. Jakarta: Kencana Prenada Media Group.

Chintya, Stephanie. Angga, Dewi \& Hutomo, Setio Budi Hendro. (2015). Tingkat kompetensi dan Kinerja Praktisi Public Relations Rumah sakit. Jurnal. http://ejournal.uajy.ac.id/4631/1/Jurnal.pdf.

Cholisoh, Nur dan Yenita. (2015). Strategi Komunikasi Public Relations dan Citra Positif Organisasi (Kasus Public Relations Rumah Sakit X di Jakarta). 13(3), 196-197.

http://jurnal.upnyk.ac.id/index.php/ko munikasi/article/view/1459

Damayanti, Novita dan Saputro, Dio Hemanto. (2017). Profesi Public Relations Di Indonesia Dalam Kajian Gender. 16 (1), $27-42$.

http://journal.moestopo.ac.id/index.php /wacana/article/view/13

Denzim, Norman K. and Lincoln, Yvonna S (2009). Handbook of Qualitative
Researche. Penterjemah ; Dariyanto, dkk. Yogyakarta : Pustaka Pelajar.

Hartini, Tin. (2019). Upaya Perhumas Dalam Meningkatkan Kompetensi Public Relations. 4 (1), 34-52 http://jurnal.unismabekasi.ac.id/index.p $\mathrm{hp} / \mathrm{makna} /$ article/view/1671

Hidayat, N. Dedy. (2003). Paradigma dan Metodologi Penelitian Sosial Empirik Klasik. Departemen Ilmu Komunikasi FISIP Universitas Indonesia. Jakarta.

Kasali, Renald. (2017). Disruption. Jakarta. PT. Gramedia Pustaka Utama.

Laksamana, Agung. (2018). Public Relations in Age of Disruption. Jakarta. PT. Bentang Pustaka.

Lubis, Mahdalena. (2017). Pencapaian Brand Corporate Melalui Brand Activation Pendekatan Experiential Marketing ( Kasus Laboratorium Klinik). 9(1), 2528 $-2727$.

https://journal.untar.ac.id/index.php/ko munikasi/article/view/457

Majalah PR Indonesia. Edisi 41/Th IV/Agustus 2018. Bersatulah Mempiarkan Indonesia. Jakarta. PT. Aksara Grafika Pratama. ISSN : 977207923008

Moleong J, Lexy. (2010). Medote Penelitian Kulitatif. PT.Remaja Rosda Karya. Edisi Revisi. Jakarta.

Nova, Firsan. (2011). Crisis Public Relations : Strategi PR Menghadapi Krisis, Mengelola Isu, Membangun Citra, dan Reputasi Perusahaan. Jakarta. PT Rajagrafindo Persada.

Primarni, Amie. (2015). Reposisi Peran Dan Fungsi Strategis Public Relations Dalam Organisasi Pendidikan. Jurnal Lentera Komunikasi. Hubungan Masyarakat, Politeknik LP3I Jakarta. 1(1), $\quad 2442 \quad-\quad 2991$ https://plj.ac.id/ojs/index.php/jrksi/artic le/view/126

Ruslan, Rosady, (2010). Metode Penelitian Public Relations dan Komunikasi. Rajawali Pers. Jakarta.

Savitri, Baiq Vira. Bakti Iriana \& Hafiar, Hanny. (2019). Profesi Humas Rumah 
Sakit : Antara Profesional dan Humanisme. 4(1), 47-67.

http://jurnal.unpad.ac.id/profesihumas/article/view/16502/11431

Siamtupang, Oktalina. (2020). Kompetensi Humas Pemerintah Dalam Menghadapi Revolusi Industri 4.0. 21(1) https://www.researchgate.net/publicati on/342090415_KOMPETENSI_HUM AS_PEMERINTAH_DALAM_MENG HADAPI_ERA_INDUSTRI_40

www.yankes.kemkes.go.id/read-peluang-dantantangan-rumah-sakit-dalam-mea755.html. Diakses tanggal 24 Desember 2019. 14.14 WIB.

www.persi.or.id/images/2017/litbang/rsindone sia418.pdf. Diakses tanggal 24 Desember 2019. 14.30 WIB

Yin K, Robert. (1997). Studi Kasus : Desain dan Metode. PT. Raja Grafindo Persada. Jakarta.

Zulfikar, Ahmad. Sultan, Moeh Iqbal \& Kahar. (2017). Peran Humas Dalam
Meningkatkan Citra Rumah Sakit Dr. Wahidin Sudirohusodo Sebagai Rumah Sakit Berstandar Internasional. Jurnal Komunikasi Kareba. Vol.6 No.1 Januari - Juni 2017. Fakultas Ilmu Sosial dan Politik Universitas Hasanuddin. https://journal.unhas.ac.id/index.php/ka reba/article/view/5169 